\title{
Broad-Range PCR in Selected Episodes of Prosthetic Joint Infection
}

The use of eubacterial PCR of the 16S rRNA (PCR) for diagnosing prosthetic-joint-associated infections (PJIs) is still a matter of debate. Several drawbacks need to be considered when using this technique, including the lack of susceptibility results (except for methicillin-resistant Staphylococcus aureus) and problems in identifying a mixture of bacterial species in a single specimen [1]. A number of studies have indicated that the routine use of PCR in PJIs does not offer a diagnostic advantage over bacterial culture [2-4]. However, this molecular method can detect bacterial DNA in samples when conventional cultures are negative due to previous antimicrobial exposure or unfavorable growth conditions. Taking these considerations into account, we use PCR only if the chance of bacterial growth is low because of previous surgical and antimicrobial treatment or previous negative culture results. In order to (re)assess the diagnostic value of PCR in those selected episodes of suspected PJI in which this method had been applied, we performed a retrospective study to define patient characteristics and to estimate the specificity and sensitivity of PCR versus bacterial culture. Our orthopedic surgery clinic is a 48-bed unit that acts as a primary care center for all types of orthopedic surgery of the extremities and as a tertiary care center for patients needing revision arthroplasty.

The study population consisted of patients with a joint prosthesis who were seen at our clinic from 2001 through 2005, and from whom specimens for bacterial culture and PCR were obtained because of possible PJI. The suspicion of PJI was based on clinical signs such as joint pain, effusion, erythema and warmth at the implant site, and/or implant loosening. Patient history prior to the diagnostic intervention was assessed for (1) antimicrobial treatment, (2) number of revisions performed on the affected joint, (3) confirmed and treated infection involving the affected joint within the last 24 months, and (4) implant loosening $\leq 12$ months after implantation without other clinical signs of infection. Specimens (synovial fluid and/or biopsies from periprosthetic tissue) were obtained either during aspiration prior to surgery or during arthroscopy or open surgery. Bacterial culture and histopathologic diagnostics were performed as described previously [5]. The decision whether or not to use PCR was made by the physicians in charge following a review of the patient's history and prior to the intervention. However, the physicians were not involved in either analyzing or inter- preting the data. Specimens were sent to a reference laboratory for analysis [6]. The technique is based on the amplification of bacterial $16 \mathrm{~S}$ ribosomal DNA [6]. Criteria for definite PJI included the presence of a sinus tract communicating with the prosthesis or purulence surrounding the prosthesis at the time of surgery or acute or chronic inflammation consistent with infection on histopathologic examination [1, 7]. Infection was excluded when the above-mentioned criteria were not fulfilled, no antimicrobial treatment was administered after the episode, and no relapse occurred for at least 1 year.

Specimens for both PCR and bacterial culture were obtained in 29 episodes of possible PJI among 26 patients. This number accounted for $7.6 \%$ (23 episodes) of all revision arthroplasties $(n=301)$ and $6.8 \%$ (6 episodes) of all joint punctures $(n=88)$ during the study period. Patient characteristics are presented in table 1. Most episodes $(48 \%)$ included a history of three or more surgical interventions (median 4, IQR 3-5) on the affected joint within a median time of 3.25 years (IQR $0.9-10.5$ ) prior to the diagnostic intervention. The median number of obtained specimens per patient for bacterial culture was five (IQR 3-7) and for PCR, one (IQR 1-2).

No infection was present in 17 (59\%) of the 29 episodes, although the duration of follow-up was $\leq 12$ months in

Infection 2009; 37: 292-294

DOI 10.1007/s15010-008-8246-1

\footnotetext{
F.H.R. De Man

Clinic of Orthopaedic Surgery, Kantonsspital, Liestal, Switzerland

P. Graber

Unit of Infectious Diseases, Basel University Medical Clinic Liestal, Liestal, Switzerland

M. Lüem

Clinic of Orthopaedic Surgery, Kantonsspital, Liestal, Switzerland

w. Zimmerli

Unit of Infectious Diseases, Basel University Medical Clinic Liestal, Liestal, Switzerland

P.E. Ochsner

Clinic of Orthopaedic Surgery, Kantonsspital, Liestal, Switzerland

P. Sendi (corresponding author)

Unit of Infectious Diseases, Basel University Medical Clinic Liestal, Rheinstrasse 26, 4410 Liestal, Switzerland; Phone: (+41/61) 925-2180, Fax: -2804, e-mail: sendi-pa@magnet.ch
}

Received: July 21, 2008 - Revision accepted: October 6, 2008 Published online: April 23, 2009 


\begin{tabular}{|c|c|}
\hline \multicolumn{2}{|c|}{$\begin{array}{l}\text { Table } 1 \\
\text { Demographic data and history of } 26 \text { patients with } 29 \text { episodes } \\
\text { of suspected prosthetic-joint-associated infections (PJIs) from } \\
\text { whom specimens for bacterial culture and broad-range PCR } \\
\text { were obtained. }\end{array}$} \\
\hline Characteristic & $\begin{array}{l}\text { Number of } \\
\text { episodes (\%) }\end{array}$ \\
\hline Median age (years) & 70.5 (range $53-80$ ) \\
\hline \multicolumn{2}{|l|}{ Sex } \\
\hline Male & 13 \\
\hline Female & 13 \\
\hline \multicolumn{2}{|l|}{ Affected joint } \\
\hline Hip & $13(44.8 \%)$ \\
\hline Knee & $16(55.2 \%)$ \\
\hline \multicolumn{2}{|l|}{ Patient history prior to presentation } \\
\hline $\begin{array}{l}\geq 3 \text { revisions performed at the } \\
\text { affected joint }\end{array}$ & $14(48 \%)$ \\
\hline $\begin{array}{l}\text { Confirmed and treated infection at the } \\
\text { affected joint within } \leq 24 \text { months }\end{array}$ & $9(31 \%)$ \\
\hline Previous antimicrobial treatment & $8(27.5 \%)$ \\
\hline $0-2$ Weeks prior to intervention & 3 \\
\hline 2-4 Weeks prior to intervention & 1 \\
\hline 4-8 weeks prior to intervention & 4 \\
\hline $\begin{array}{l}\text { Implant loosening } \leq 12 \text { months after } \\
\text { implantation without other clinical signs } \\
\text { of infection }\end{array}$ & $6(21 \%)$ \\
\hline
\end{tabular}

two cases (4, 11 months) due to non-episode-related death and loss to follow-up, respectively. The PCR was negative in all 17 cases with clinically excluded infection. In contrast, there was bacterial growth in five episodes, but these were interpreted as contamination. In the infection episodes, one inaccurate PCR result was considered to be a false-positive. Based on these findings, the specificity for bacterial culture was $71 \%$ and for PCR 94\%.

The criteria for PJI were fulfilled in $12(41 \%)$ of the 29 episodes; this accounted for $8.5 \%$ of 142 confirmed PJI episodes (including 62\% referred cases) during the study period. The results of bacterial culture and PCR are presented in table 2 . In five episodes, both diagnostic approaches identified the same microorganism. However, in two of these, PCR revealed only one pathogen, while two distinct microorganisms grew in culture. In two further episodes, the pathogen was identified either only by bacterial culture or only by PCR. Hence, the sensitivity for bacterial culture was $58 \%$ and for PCR, $50 \%$.

Little information is available for assisting clinical practitioners in selecting episodes in which PCR may be superior or complementary to bacterial culture for diagnosing PJI. The previous history of the patients included in this study (Table 1) highlights the importance of distinguishing PJI from other causes of joint failure. Based on this history, we decided it was reasonable to expand diagnostic means by an additional tool in these selected episodes.

Broad-range PCR and more advanced molecular methods show a high specificity $(96 \%-100 \%)$ [3, 4, 8-12], but often a poor sensitivity $(\leq 50 \%)$ in diagnosing PJI $[3,4,8,10,12]$. Similarly, the specificity was excellent in

Table 2

Results of bacterial culture and broad-range PCR in 12 episodes of confirmed PJI.

\begin{tabular}{|c|c|c|c|c|c|}
\hline \multirow[t]{2}{*}{ Episode } & \multirow[t]{2}{*}{ Sample origin } & \multicolumn{2}{|l|}{ Bacterial culture } & \multicolumn{2}{|l|}{$16 S$ rRNA-PCR } \\
\hline & & $\begin{array}{l}\text { Number of positive/ } \\
\text { total number } \\
\text { of specimens }\end{array}$ & Pathogen & $\begin{array}{l}\text { Number of positive/ } \\
\text { total number of } \\
\text { specimens }\end{array}$ & Pathogen \\
\hline 1 & Synovial fluid & $2 / 2$ & Streptococcus pyogenes & $1 / 1$ & Streptococcus pyogenes \\
\hline $2^{a}$ & Periprosthetic tissue & $2 / 13$ & Propionibacterium sp. & $1 / 8$ & Streptococcus infantis \\
\hline 3 & Synovial fluid & $1 / 1$ & Staphylococcus aureus & 1 & Negative \\
\hline 4 & Periprosthetic tissue & 1 & No growth & 1 & Negative \\
\hline 5 & Periprosthetic tissue & 1 & No growth & 1 & Negative \\
\hline 6 & Synovial fluid & 1 & No growth & $1 / 1$ & Streptococcus bovis \\
\hline 7 & Periprosthetic tissue & $\begin{array}{l}5 / 11 \\
1 / 11\end{array}$ & $\begin{array}{l}\text { Staphylococcus aureus } \\
\text { Enterococcus faecalis }\end{array}$ & $1 / 1$ & Staphylococcus aureus \\
\hline 8 & Periprosthetic tissue & 6 & No growth & 2 & Negative \\
\hline 9 & Periprosthetic tissue & $6 / 9$ & Staphylococcus epidermidis & $1 / 1$ & Staphylococcus epidermidis \\
\hline 10 & Periprosthetic tissue & $\begin{array}{l}5 / 6 \\
1 / 6\end{array}$ & $\begin{array}{l}\text { Pseudomonas aeruginosa } \\
\text { Enterococcus faecalis }\end{array}$ & $2 / 2$ & Pseudomonas aeruginosa \\
\hline 11 & Periprosthetic tissue & $1 / 5^{\mathrm{b}}$ & Staphylococcus epidermidis & $1 / 1$ & Staphylococcus epidermidis \\
\hline 12 & Periprosthetic tissue & 5 & No growth & 1 & Negative \\
\hline
\end{tabular}


our selected episodes. In all episodes with a previous history of multiple revisions or previously treated PJI, PCR remained negative when no infection was present. Also, in only one out of six episodes with early implant loosening ( $\leq 12$ months after implantation) but no other clinical signs of PJI was an infection present, and the PCR results matched accordingly. Importantly, in five episodes, PCR was useful in identifying false-positive results from bacterial culture.

The sensitivity of the PCR, however, was poor (50\%). The overall sensitivity in diagnosing PJI increased to $67 \%$ when both PCR and bacterial culture were considered together (i.e. one or other or both positive). Since our study was performed retrospectively, and patients selected for PCR were not recruited according to strictly predefined criteria, the study could have been influenced by a selection bias. Therefore, no immediate recommendation about the use of PCR in PJI can be made.

However, the expense and diagnostic value of PCR in comparison to bacterial culture [2-4] warrant the use of this molecular method only selectively and not routinely, and in addition to bacterial culture. In our center, PCR has been performed in fewer than $10 \%$ of all revision arthroplasties (i.e. in patients with a complex history of joint disease) and found to have only a limited diagnostic value. In fewer than $20 \%$ of the episodes, PCR was helpful in recognizing false-positive culture results. In terms of the applicability of PCR in clinical practice, more studies are required to identify both a patient population and a diagnostic strategy in which the use of such a molecular tool is beneficial in diagnosing or excluding PJIs.

\section{F.H.R. De Man, P. Graber, M. Lüem, W. Zimmerli, P.E. Ochsner, P. Sendi}

\section{Acknowledgments}

This work was presented in part at the 45th Interscience Conference on Antimicrobial Agents and Chemotherapy, Washington D.C., 16-19 December 2005 (abstract K-876). We thank Dr. Susanne Graf and the laboratory technicians from our Unit of Microbiology for their superb assistance. Financing disclosure: F.H.R. De Man received grants from the AO foundation, and M. Lüem received grants from the Wissenschaftfonds Orthopaedie Kantonsspital Liestal.
Conflict of interest statement. None of the authors have a conflict of interest.

\section{References}

1. Trampuz A, Steckelberg JM, Osmon DR, Cockerill FR, Hanssen $A D$, Patel R: Advances in the laboratory diagnosis of prosthetic joint infection. Rev Med Microbiol 2003; 14: 1-14.

2. Panousis K, Grigoris P, Butcher I, Rana B, Reilly JH, Hamblen DL: Poor predictive value of broad-range PCR for the detection of arthroplasty infection in 92 cases. Acta Orthop 2005; 76: 341-346.

3. Kordelle J, Hossain H, Stahl U, Schleicher I, Haas H: Usefulness of $16 \mathrm{~S}$ rDNA polymerase-chain-reaction (PCR) in the intraoperative detection of infection in revision of failed arthroplasties. Z Orthop Ihre Grenzgeb 2004; 142: 571-576.

4. Kordelle J, Klett R, Stahl U, Hossain H, Schleicher I, Haas H: Infection diagnosis after knee-TEP-implantation. $Z$ Orthop Ihre Grenzgeb 2004; 142: 337-343.

5. Zappe B, Graf S, Ochsner PE, Zimmerli W, Sendi P: Propionibacterium spp. in prosthetic joint infections: a diagnostic challenge. Arch Orthop Trauma Surg 2008; 128: 1039-1046.

6. Bosshard PP, Kronenberg A, Zbinden R, Ruef C, Bottger EC, Altwegg $M$ : Etiologic diagnosis of infective endocarditis by broad-range polymerase chain reaction: a 3-year experience. Clin Infect Dis 2003; 37: 167-172.

7. Berbari EF, Marculescu C, Sia I, Lahr BD, Hanssen AD, Steckelberg JM, Gullerud R, Osmon DR: Culture-negative prosthetic joint infection. Clin Infect Dis 2007; 45: 1113-1119.

8. Mariani BD, Martin DS, Levine MJ, Booth RE Jr, Tuan RS: The Coventry Award. Polymerase chain reaction detection of bacterial infection in total knee arthroplasty. Clin Orthop Relat Res 1996; 331: 11-22.

9. Moojen DJ, Spijkers SN, Schot CS, Nijhof MW, Vogely HC, Fleer A, Verbout AJ, Castelein RM, Dhert WJ, Schouls LM: Identification of orthopaedic infections using broad-range polymerase chain reaction and reverse line blot hybridization. J Bone Joint Surg Am 2007; 89: 1298-1305.

10. Fihman V, Hannouche D, Bousson V, Bardin T, Liote F, Raskine L, Riahi J, Sanson-Le Pors MJ, Bercot B: Improved diagnosis specificity in bone and joint infections using molecular techniques. J Infect 2007; 55: 510-517.

11. Fenollar F, Roux V, Stein A, Drancourt M, Raoult D: Analysis of 525 samples to determine the usefulness of PCR amplification and sequencing of the 16S rRNA gene for diagnosis of bone and joint infections. J Clin Microbiol 2006; 44: 1018-1028.

12. Hoeffel DP, Hinrichs SH, Garvin KL: Molecular diagnostics for the detection of musculoskeletal infection. Clin Orthop Relat Res 1999; 360: 37-46. 